\title{
Consumption of different types of meat and the risk of renal cancer: meta-analysis of case-control studies
}

Mohammed F. Faramawi · Eric Johnson •

M. Whitney Fry · Macodu Sall · Yi Zhou

Published online: 1 March 2007

(C) Springer Science+Business Media B.V. 2007

Erratum to: Cancer Causes Control 18: 125-133

DOI 10.1007/s10552-006-0104-9

The name of the last author was erroneously given as Zhou Yi. It should be Yi Zhou.

The online version of the original article can be found at http:// dx.doi.org/10.1007/s10552-006-0104-9

M. F. Faramawi $(\square) \cdot$ M. W. Fry · M. Sall ·

Y. Zhou

Epidemiology Department, Tulane University School of

Public Health \& Tropical Medicine, 1440 Canal Street Suite,

2000, New Orleans, LA 70112, USA

e-mail:melfaram@tulane.edu

E. Johnson · Y. Zhou

University of North Texas Health Science Center, Fort

Worth, USA 